\title{
Abundance and spatial distribution of Polygordius (Polychaeta: Polygordiidae) neustonic exolarvae in estuaries from southern Chile
}

\author{
Abundancia y distribución espacial de exolarvas neustónicas de \\ Polygordius (Polychaeta: Polygordiidae) en estuarios del sur de Chile
}

Juan I. Cañete ${ }^{1}$, Carlos S. Gallardo², Álvaro Medina ${ }^{3}$, Javier Díaz-Ochoa ${ }^{1}$, Carlos Olave ${ }^{4} \&$ Tania Figueroa ${ }^{1}$

\begin{abstract}
Integration of meroplankton abundance and hydrographic data was employed to relate the Polygordius exolarvae spatial dynamics with different salinity gradients in order to define the factors that regulate the abundance and spatial distribution along the large estuarine system from southern Chile. The present study aims: i) record the abundance and spatial distribution of Polygordius neustonic exolarvae along of the estuaries with different gradients of salinity located between Guafo Channel, southern Chiloé Island $\left(44^{\circ}\right.$ S) to Navarino Island $\left(55^{\circ} \mathrm{S}\right)$, Chile; ii) connect this distributional pattern to oceanographic parameters to determine if members of this genus have adapted to euryhaline or stenohaline conditions, and iii) establish a comparison between the abundance of Polygordius and others meroplanktonic taxa collected during CIMAR Cruises 16, 18 and 20 Fjords. Neustonic samples were collected during three oceanographic cruises along southern Chilean fjord/channel systems $(\sim 1,700 \mathrm{~km})$ with different freshwater supply regimes (CIMAR 16: October/November, 2010, $52^{\circ}$ to $55^{\circ} \mathrm{S}$; CIMAR 18: June/July, 2012, $44^{\circ}$ to 47으 S; CIMAR 20: October, $2014,47^{\circ}$ to $50^{\circ} \mathrm{S}$ ), providing evidence to relate the influence of surface salinity on the Polygordius exolarvae spatial distribution of abundance. Polygordius exolarvae (average length $=2.9 \pm 0.8 \mathrm{~mm}$ ), the most abundant meroplanktonic taxa within the neustonic community $(54.04 \%$ of total abundance; 66,228 individuals; $\mathrm{N}_{\text {Total }}=26$ stations), was represented at $81 \%$ of stations sampled in CIMAR
\end{abstract}

16 (mean salinity=30.7 psu), showing higher abundance (1,518 ind. x 5 min of horizontal drag) than for other polychaete larvae (10 types) and other meroneustonic taxa; $60 \%$ of the abundance of exolarvae during CIMAR 16 was collected around Dawson Island, Magellan Strait. In CIMAR 18 cruise (mean salinity $=24.28 \mathrm{psu}$ ), abundance of exolarvae was low (3 ind. x 5 min of horizontal drag) and were collected only at 5 stations along the Moraleda Channel ( $\mathrm{N}_{\text {Total }}=31$ stations); no exolarvae were collected during CIMAR 20 ( $\mathrm{N}_{\text {total }}=39$ stations) (mean salinity= 23.26 psu). Polygordius exolarvae have narrow haline/thermal requirements during their pelagic life, where sills and island mass effect could produce a restricted and aggregated spatial distribution in some areas of the study zone.

\section{Key words:}

Polychaeta, subantarctic meroneuston, estuaries, Oximax zone, CIMAR Fjord Cruises.

\section{Resumen}

Se integraron datos hidrográficos y abundancia del meroplancton para determinar la posible

\footnotetext{
Laboratorio de Oceanografía Biológica Austral (LOBA),

Departamento de Ciencias y Recursos Naturales, Facultad Ciencias, Universidad de Magallanes,

Punta Arenas, Chile. $\gg$ ivan.canete@umag-cl

2 Instituto Ciencias Marinas y Limnológicas, Facultad de Ciencias, Universidad Austral de Chile, Valdivia, Chile.

3 Instituto de Fomento Pesquero, Punta Arenas, Chile.

4 Centro de Estudios del Cuaternario, CEQUA,

Punta Arenas, Chile.
} 
influencia de la salinidad sobre la dinámica espacial de la abundancia de exolarvas del poliqueto Polygordius sp. en estuarios del sur de Chile. Los objetivos del presente estudio fueron: i) determinar la abundancia y la distribución espacial de exolarvas neustónicas del poliqueto Polygordius en una zona estuarial con diferentes gradientes de salinidad localizada entre el canal Guafo, sur de

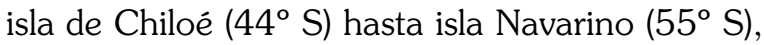
Chile; ii) relacionar este patrón distribucional con las características oceanográficas de la zona de estudio para determinar la respuesta adaptativa de las larvas ante gradientes halinos y termales, y, iii) comparar la abundancia larval de Polygordius en relación a otros taxa meroplanctónicos recolectados durante los cruceros CIMAR 16, 18 y 20. El análisis del neuston de la zona de fiordos y canales del sur de Chile posee diferentes regímenes de aportes de agua dulce (CIMAR 16 - octubre/noviembre de 2010 y $52^{\circ}$ a $55^{\circ}$ de latitud; CIMAR - 18 junio/julio, 2012 y $44^{\circ}$ a $47^{\circ}$ de latitud; CIMAR - 20 octubre/noviembre de 2014 y $47^{\circ}$ a $50^{\circ}$ de latitud), demostrando una relación entre la salinidad superficial y la abundancia de exolarvae. Las exolarvas de Polygordius (longitud promedio=2,9 $\pm 0,8 \mathrm{~mm}$ ) fueron el estadio meroneustónico más abundante dentro de la comunidad $(54,04 \%$ de la abundancia total; 66.228 individuos; $\mathrm{N}=26$ estaciones) $y$ estuvieron representadas en $81 \%$ de las estaciones de CIMAR 16 (salinidad promedio=30,7 psu) y dominaron en abundancia sobre larvas de otros poliquetos (10 tipos); en CIMAR 16, 60\% de las exolarvas se recolectaron alrededor de la isla Dawson, estrecho de Magallanes. En CIMAR 18 (salinidad promedio=24,28 psu), las exolarvas solo fueron recolectadas a lo largo del canal Moraleda ( $\mathrm{N}=5 / 31$ estaciones). En CIMAR $20 \quad(\mathrm{~N}=39$ estaciones), no fueron recolectadas exolarvas (salinidad promedio=23,26 psu). Las exolarvas de Polygordius poseen estrechos requerimientos de temperatura y salinidad durante su vida pelágica, y la agregación de larvas podría ser provocada por umbrales submarinos y efecto isla en la zona de estudio.

\section{Palabras clave:}

Polychaeta, meroneuston subantártico, estuarios, zonas Oximax, Cruceros CIMAR Fiordos.

\section{INTRODUCTION}

The biodiversity levels and densities of neustonic organisms, their spatial and temporal variation, their roles in sustaining biogeochemical cycling and atmosphere-ocean exchange processes, as well as a nutritional source for important trophic networks in significant areas of the oceans, all remain unknown (Hardy, 2005). The present study describes the structure and biodiversity of neustonic communities in southern Chile, which includes an extended estuarine environment with roughly $1,700 \mathrm{~km}$ of fragmented coastline. This area is characterized by the largest fjord systems in the world where salty Subantarctic Surface Water and Modified Subantarctic Waters mix with freshwater, generating sharp vertical and horizontal salinity gradients. These salinity gradients create strong biological consequences, including a stratification effect caused by buoyancy, which is a key regulator of primary production and biomass, a limitation on the depth of turbulent mixing, keeping algal cells within the photic zone; the concentration of an important fraction of organic matter and planktonic communities; and a change in the abundance and spatial distribution of the neuston (Dávila et al. 2002; Silva \& Palma, 2008; Pantoja et al. 2011; Iriarte et al. 2014; Cañete et al. 2016).

The neuston represents the atmosphericoceanic interface which can be thought of as the ocean's skin, given that it is only a few centimeters thick (Hardy, 1991; Upstill-Goddard et al. 2003), and covers $71 \%$ of the planet's surface. The physical processes occurring there are critical to the global conservation of biogeochemical cycles, but latitudinal differences in the neuston's environmental functions, such as fragmentation and transport of organic matter to greater depths, are not well understood (Zaitsev, 2005; Koski et al. 2007). In temperate zones, the neuston plays an important trophic role as a food source for meso- and macrozooplankton and is a key component in the production of "marine snow" and the vertical transport of organic material from the ocean surface to greater depths (Conte et al. 1998; Zaitsev, 2005; Hays et al. 2005; Koski et al. 2007). Furthermore, mesozooplankton living here are crucial to the sustenance and survival of 
important fisheries (Zaitsev, op. cit.). For these reasons, it would be very useful to understand how the neuston is influenced by environmental and oceanographic factors, including temperature, solar radiation, salinity, and acidification (Hardy, 1991; Rodríguez et al. 2000; Zaitsev, op. cit.); and are important themes in oceanographic research that are associated with climatic warming and oceanographic change in sub-polar marine ecosystems (Zaitsev, op. cit.). Recents research on estuarine neustonic communities in the western margin of Magellan Region showed a large diversity of larval polychaete shapes, and that these polychaetes were the second most abundant taxon in this meroneustonic community (Cañete et al. 2016). The most typical shape among the polychaete was the "banana larvae", which were eventually assigned to the Polygordius genus, whose larvae has been described in coastal waters of the eastern United States (e.g. Ramey et al. 2006; Ramey, 2008; Ramey \& Bodnar, 2008; Ramey-Balci \& Ambler, 2014).

Polygordius show a somewhat unusual larval development, with two distinct planktonic larval forms: an exolarva and an endolarva, which differ greatly in their morphology and development. In the exolarva, the worm-like trunk gradually elongates as new segments form posterior to the hyposphere (Hatschek 1878). However, in the endolarva, segments developing on the trunk of the worm stay folded up inside the hyposphere until metamorphosis (Loven, 1843; Ramey-Balci \& Ambler, 2014).

Different to Polygordius found off the east coast of the United States, there is no information about the life cycle of members of the genus Polygordius in Chilean waters, neither of other members of class Archiannelida (Rozbaczylo, 1985). Indeed, several studies of pelagic communities in the Strait of Magellan and the Beagle Channel (Marín \& Antezana, 1985; Mazzocchi et al. 1995; Hamamé \& Antezana, 1999; Marín \& Delgado, 2001) make no reference to the presence of Polygordius larvae (Biancalana et al. 2007; Aguirre et al. 2012). However, some benthic studies in the southern Chile demonstrate of abundant population in sedimentary intertidal flat of estuarine system from southern Chile (Acuña et al. 2012; Pino et al. 2015).
No studies on Polygordius larval life has been carried out along Chilean coast. Integration of meroplankton abundance and hydrographic data could be used to relate the Polygordius exolarvae spatial dynamics with different salinity gradients along the large estuarine system from southern Chile in order to define their physiological requirements with field data. Thus, estuaries with different supplies of freshwater and a wide range of surface salinities could to affect the abundance and spatial distribution of neustonic species.

The present study aims: i) record the abundance and spatial distribution of Polygordius neustonic exolarvae along of the estuaries with different gradients of salinity located between Guafo Channel, southern Chiloé Island (44 S) to Navarino Island $\left(55^{\circ} \mathrm{S}\right)$, Chile; ii) connect this distributional pattern to oceanographic parameters to determine if members of this genus have adapted to euryhaline or stenohaline conditions, and iii) establish a comparison between the abundance of Polygordius and others meroplanktonic taxa collected during CIMAR Cruises 16, 18 and 20 Fjords.

\section{MATERIAL AND METHODS}

Sampling (Fig. 1a-c) was conducted during CIMAR Fjord Cruises 16 (October 11 to November 19, 2010), CIMAR 18 (June 16 to July 12, 2012), and CIMAR 20 (October 2 to 27, 2014). CIMAR 16 sampled the western mouth of the Magellan Strait to the Beagle Channel, Almirantazgo Sound and Inútil Bay, and channels and islands closer to the Pacific Ocean. Sampling along the eastern margin of the Magellan Strait (which would have covered stations 1-6) was not possible due poor weather conditions. The CIMAR 18 sampling area was between the Guafo Channel $\left(44^{\circ} \mathrm{S}\right)$ and Elephant Fjord $\left(47^{\circ} \mathrm{S}\right)$, and the CIMAR 20 area was between latitude $47^{\circ} \mathrm{S}$ and $50^{\circ} \mathrm{S}$. Sampling on CIMAR 16 and 18 took place on the VR Abate Molina and the AGS 61 Cabo de Hornos was used on CIMAR 20.

Surface sampling was conducted at each station using a neuston net $(80 \mathrm{~cm}$ wide and 30 $\mathrm{cm}$ deep) with a $50 \mu \mathrm{m}$ wide zooplankton mesh for sampling the centilayer and surface layer (Hardy, 


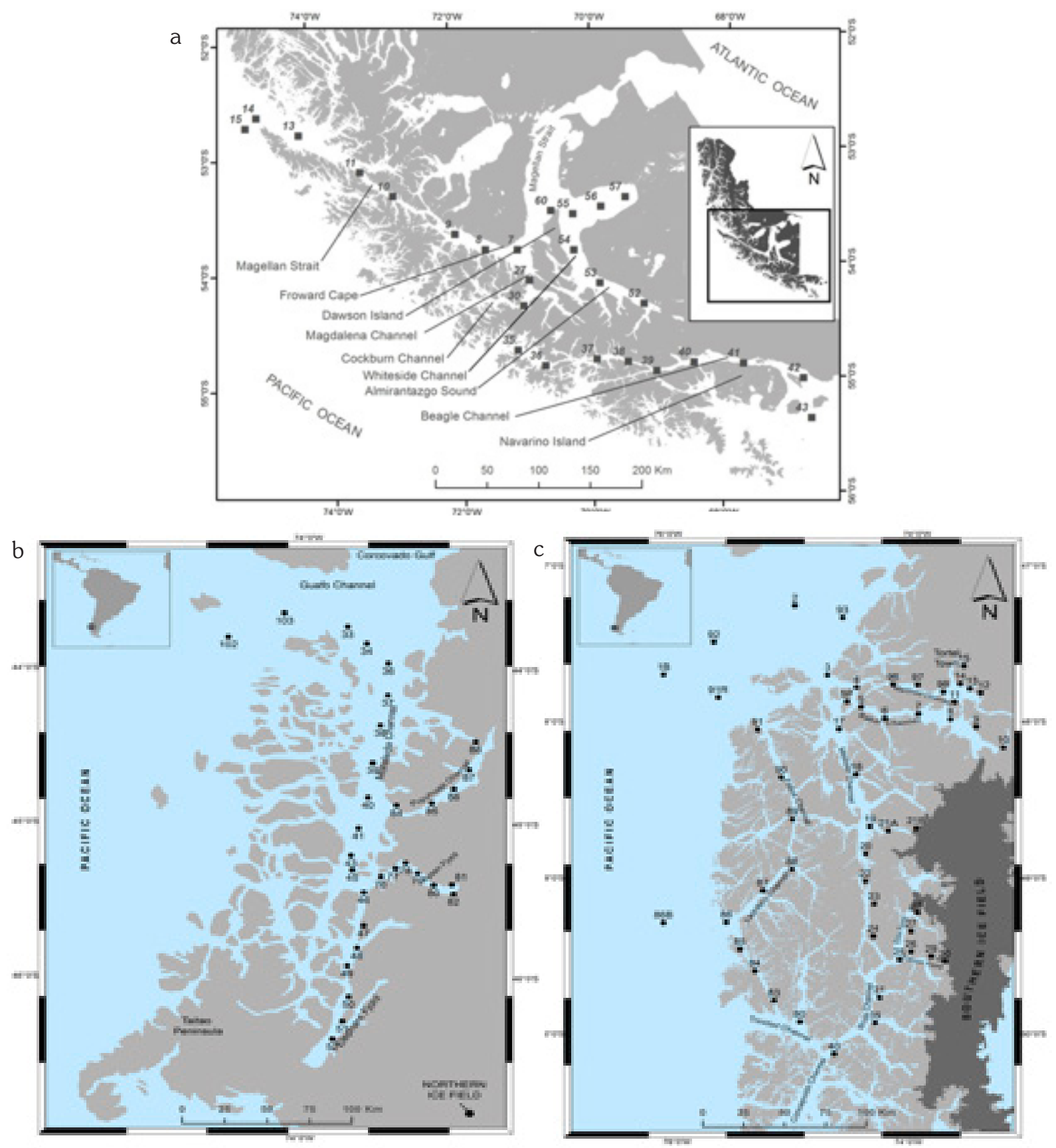

Fig. 1. Geographic locations of sampling stations of the three CIMAR Fjord Cruises, southern Chile: a) CIMAR 16, Western Magellan Region, b) CIMAR 18, section from the Guafo Channel to Elephant Fjord and c) CIMAR 20, section from the Penas Gulf to the Trinidad Channel.

2005). Speed was reduced to 1 to 2 knots and the neuston net was dragged along the surface. This was initially done for 8 minutes (stations 7 , 8 , and 9), but this was reduced to 5 minutes at all other sampling sites, due to the high concentration of neuston collected. In addition, a profile was performed with a rosette equipped with a CTD Sea-Bird Model 19 that was submerged to different 
depths according to the bathymetric features of each site (Data Report CIMAR Fjord Cruises 16, 18 , and 20). Since the neuston lives in the surface layers, data for temperature, salinity, and dissolved oxygen were averaged at between 1 and 2 meters depth for each station.

Biological samples were fixed with $5 \%$ neutralized formalin. In the laboratory, the whole sample was filtered through a $30 \mu \mathrm{m}$ mesh for wet biomass determination, including phytoneuston and zooneuston together. Next, the samples were divided with a Folsom fractionator to $1 / 8$ of total content. The neuston taxa were identified by phylum, class and as requested, and were independently counted under a stereoscopic microscope. The Polygordius exolarvae were identified using descriptions of $P$. jouinae larval development (Ramey-Balci \& Ambler, 2014).

Density was calculated as the total number of individuals collected during five minutes of horizontal drag of the neustonic net in the surface layer of the water column. The total lengths (TL) of a subsample of fixed exolarvae were measured from the posterior stomach margin to the posterior pygidium (Fig. 4a-c). Exolarvae entering metamorphosis was measured from the anterior margin of the prostomium to the posterior margin of the pygidium, consistent with the measurements on benthic adults by Ramey (2008). All size measurements were taken using a high-resolution, 1.4 megapixel, Firewire color camera, Image MS Shot software.

\section{Data analysis on spatial}

distribution of Polygordius exolarvae

The exolarvae spatial distribution and density sampled at each station during each CIMAR Fjord Cruise were plotted on a map of the Southern Chile. The proportion of exolarvae \pm SD (standard deviation) observed in the water column surface layer in these three cruises was used to establish the general Polygordius exolarvae presence in the estuarine neuston.

Samples were stored at the Laboratorio de Oceanografía Biológica Austral (LOBA), Department of Sciences \& Natural Resources, Faculty of Sciences, Universidad de Magallanes, Punta Arenas, Chile.

\section{RESULTS}

\section{Oceanography}

During the three cruises, the spatial variability of ocean temperature, salinity, and dissolved oxygen content were measured at each station's surface layer at a depth of 1-2 m. During CIMAR 16, water temperature fluctuated between $6.16{ }^{\circ} \mathrm{C}$ (Station 52) and $8.42{ }^{\circ} \mathrm{C}$ (Station 56), with an average water temperature of $7.2 \pm 0.6$ ${ }^{\circ} \mathrm{C}$. The highest temperatures were detected in Whiteside Channel and Inútil Bay, while the lowest temperatures were detected along the western side of the Strait of Magellan and in the Almirantazgo Sound, near the glacial discharge from the Darwin Ice Field. Salinity ranged from 26.051 psu (Station 51) to 32.777 psu (Station 15), with an average salinity of $30.7 \pm 0.91$. Values corresponding to 32 to 33 psu were recorded for stations in the Strait of Magellan and Fuegian channels, while that only $4 \%$ of stations showing salinities less than 27 psu ( $\mathrm{N}=26$ stations). Dissolved oxygen content ranged from $6.66 \mathrm{~mL} \mathrm{O}_{2} \mathrm{~L}^{-1}$ (Station 15) to $8.27 \mathrm{~mL} \mathrm{O}_{2}$ $\mathrm{L}^{-1}$ (Station 55), with an average of $7.4 \pm 0.4 \mathrm{~mL}$ $\mathrm{O}_{2} \mathrm{~L}^{-1}$, with a maximum value recorded in a glacial area of Almirantazgo Sound (Table 1).

During CIMAR 18, water temperature measurements ranged between $5.5{ }^{\circ} \mathrm{C}$ (Station 80) and $10.1{ }^{\circ} \mathrm{C}$ (Station 103), with an average water temperature of $8.3 \pm 1.4{ }^{\circ} \mathrm{C}$. The highest temperatures were detected in the open ocean, while the lowest temperatures were detected within the Aysén Fjord. Salinity ranged from 4.96 psu (Station 80) to 33.36 psu (Station 103), with an average salinity of $24.37 \pm 8.35$. Salinities corresponding to inner waters were the lowest, with $45 \%$ of stations showing salinities less than 27 psu ( $\mathrm{N}=31$ stations). Dissolved oxygen content ranged from $5.49 \mathrm{~mL} \mathrm{O}_{2} \mathrm{~L}^{-1}$ (Station 102) to 8.24 $\mathrm{mL} \mathrm{O}_{2} \mathrm{~L}^{-1}$ (Station 80), with an average of $6.4 \pm$ $0.8 \mathrm{~mL} \mathrm{O}_{2} \mathrm{~L}^{-1}$, with a maximum value recorded in a glacial area of the Aysén Fjord (Table 1).

During CIMAR 20, the measured water temperature ranged between $6.8{ }^{\circ} \mathrm{C}$ (Station 28) and $10.7^{\circ} \mathrm{C}$ (Station 80), with an average water temperature of $9.3 \pm 0.8{ }^{\circ} \mathrm{C}$. The highest temperatures were detected in the Trinidad Channel and the lowest recorded along the 
Table 1. Surface oceanographic parameters (average values; 1 to $2 \mathrm{~m}$ depth) and average abundance of Polygordius exolarvae, and number of stations with estuarine salinity, all recorded during CIMAR Fjord Cruises 16, 18, and 20. In brackets is showed the number of station with

Polygordius exolarvae in relation with all stations (under average abundances).

\begin{tabular}{cccccc}
\hline Cruise & $\begin{array}{c}\text { Temperature } \\
\left({ }^{\circ} \mathrm{C}\right)\end{array}$ & $\begin{array}{c}\text { Salinity } \\
(\mathrm{psu})\end{array}$ & $\begin{array}{c}\text { Dissolved } \\
\text { Oxygen } \\
\left(\mathrm{mL} \mathrm{O}_{2} \mathrm{~L}^{-1}\right)\end{array}$ & $\begin{array}{c}\text { Average abundance of } \\
\text { Polygordius exolarvae } \\
\text { (Ind. per 5 min } \\
\text { horizontal drag) }\end{array}$ & $\begin{array}{c}\text { Stations with } \\
\text { salinity } \leq 27 \text { psu } \\
(\%)\end{array}$ \\
\hline $\begin{array}{c}\text { CIMAR 16 } \\
\text { (Spring 2010) }\end{array}$ & 7.20 & 30.70 & 7.41 & $\begin{array}{c}1518.25 \\
(21 / 26)\end{array}$ & 3.9 \\
\hline $\begin{array}{c}\text { CIMAR 18 } \\
\text { (Winter 2012) }\end{array}$ & 8.34 & 24.28 & 6.39 & 3.16 & 45.2 \\
\hline $\begin{array}{c}\text { CIMAR 20 } \\
\text { (Spring 2012) }\end{array}$ & 9.31 & 23.26 & 7.50 & 0.00 & 70.0 \\
\hline
\end{tabular}

Eire Fjord. Salinity, ranged from 1.00 psu (Station 12) to 31.69 psu (Station 91), with an average salinity of $23.25 \pm 7.49$. Salinities corresponding to inner waters were the lowest, with $70 \%$ of stations ( $N=39$ stations) showing surface salinities $\leq 27$ psu. Dissolved oxygen content ranged from $6.7 \mathrm{~mL} \mathrm{O}_{2} \mathrm{~L}^{-1}$ (Station 23) to $8.5 \mathrm{~mL} \mathrm{O}_{2} \mathrm{~L}^{-1}$ (Station 12), with an average of $7.5 \pm 0.5 \mathrm{~mL} \mathrm{O}_{2} \mathrm{~L}^{-1}$ (Table 1 ).

\section{Exolarval morphology}

Collected specimens appeared to be at the most advanced stage of larval development, with total lengths measuring between 1.2 and $5.05 \mathrm{~mm}$ (average $=2.87 \pm 0.81 \mathrm{~mm} ; \mathrm{N}=123$ individuals), and having a small prostomial end. Not specimens showed evidence of an epishere or hyposphere, and the prototrochae and telotrochae were at both ends, with long ciliary bands (Fig. 5a-c). No larval setae were observed. The average prototrochae region width was $0.44 \pm 0.08 \mathrm{~mm}$, varying between 0.26 and $0.64 \mathrm{~mm}$. Optical electron microscopy observations revealed only two ciliary bands, an anterior prototroch and a posterior telotroch, in later stages of development, with ocelli detected over the prototroch (Fig. 4a). Medial apical organs were not observed, although primordial palps were visible (Fig. 5a).

The large variation in exolarvae length seem to indicate that trunk length increased and episphere width decreased in earlier to later stages of development. In the metamorphosis process, the head becomes progressively more distinct, and the ciliary bands become greatly reduced until they disappear completely in the juvenile (RameyBalci \& Ambler, 2014). Our specimens therefore seem be exolarvae of large size without evidence of a subsequent metamorphosis. Presence of small antennae in the anterior end of the prostomium allowed identify these exolarvae to the genus Polygordius (Patricia Ramey-Balci, com. pers., 2018, Fig. 5d).

\section{Abundance of Polygordius \\ exolarvae and response to salinity}

The highest abundance of Polygordius exolarvae was recorded during CIMAR 16, with the highest density of exolarvae (14,600 individuals per 5 min of horizontal drag) observed at station 57, in Inútil Bay (Fig. 2a). Exolarvae comprised $>54.04 \%$ of the meroneuston abundance during CIMAR 16 (Table 2), and $82.3 \%$ of total larvae were collected around Dawson Island (Fig. 2a, Fig. 3a $\&$ b), with other portions (13.2\%) of Polygordius exolarvae collected along the Beagle Channel. During CIMAR 18, a total of 98 Polygordius exolarvae (Fig. 3a \& b; Fig. 4a-d) were collected at only five stations. Abundances varied between 6 and 69 individuals per $5 \mathrm{~min}$ of horizontal drag, in the Moraleda Channel (Stations 37 to 41). No exolarvae were captured in any other study area with lowest salinity. No exolarvae of Polygordius were found at any of the stations during Cruise 20 (Table 1, Table 2). 
We hypothetized that neustonic species living in estuaries with different supplies of freshwater, could be able to tolerate a wide range of salinities (euryhaline). Polygordius exolarvae (1 to $5 \mathrm{~mm}$; average length $=2.9 \pm 0.8 \mathrm{~mm}$ ), the most abundant meroplanktonic taxa within the neustonic community (54.04\% of total abundance; 66,228 individuals; $\mathrm{N}_{\text {Total }}=26$ stations), was represented at $81 \%$ of stations sampled in CIMAR 16 (mean salinity $=30.7$ psu), showing higher abundance (1,518 ind. x 5 min of horizontal drag) than for other polychaete larvae (10 types) and other meroneustonic taxa (Table 2). In CIMAR 18 cruise (mean salinity=24.28 psu), mean abundance of exolarvae was low (3 ind. x 5 min of horizontal drag) and were collected only at 5 stations with salinities ranged between 30.4-31.6 psu along of the Moraleda Channel ( $\mathrm{N}_{\text {Total }}=31$ stations); no exolarvae were collected in surface waters with salinity ranged between 4 to 25,6 psu. No exolarvae were collected during CIMAR 20 ( $\mathrm{N}_{\text {Total }}=39$ stations) (mean salinity $=23.26 \mathrm{psu}$ ).

We demonstrate that Polygordius exolarvae have narrow haline requirements during their pelagic, larval life (stenohaline; salinity $30.0 \mathrm{psu}$ ). Thus, in both cruises with presence of exolarvae of Polygordius, narrow range of physiological response to temperature $\left(7\right.$ to $\left.10^{\circ} \mathrm{C}\right)$ and salinity (30.0 to $30.5 \mathrm{psu}$ ) was evidenced (Fig. 4a-d).

\section{Comparative abundance of Polygordius exolarvae us others meroneustonic taxa}

The contribution of Polygordius exolarvae shows a southern-northern trend, where the abundance and frequency were higher in the west side of the Magellan waters $(54 \%$ to $0 \%$ between CIMAR 16 and CIMAR 20, respectively) (Table 2). The Magellan waters also sustain an important biodiversity of the meroneustonic taxa (9) in relation to others two cruises (4 to 6). Between others types of polychaete larvae were found specimens of families Nereididae, Spionidae, Syllidae, Phyllodocidae and Polynoidae, with the Spionidae showing at least four types of chaetolarvae. In the CIMAR 18, the large contribution was realized by nauplius stages of copepod during winter condition, while in spring condition (CIMAR 20), cyphonautes of

Table 2. Comparative analysis of meroneustonic plankton collected during three cruises CIMAR Fjord

(16, 18 and 20). Between brackets are showed the total abundance and the percentage of meroneuston, respectively. $\mathrm{N}=$ number of stations sampled in each cruise; $\mathrm{f}=$ frequency.

\begin{tabular}{|c|c|c|c|c|c|c|c|}
\hline \multirow[t]{2}{*}{ Taxa } & \multirow[t]{2}{*}{ Types of Larvae } & \multicolumn{2}{|c|}{$\begin{array}{c}\text { Cimar 16 } \\
\text { Spring, } 2010 \\
(66,228 ; 41.3 \%) \\
\mathrm{N}=26\end{array}$} & \multicolumn{2}{|c|}{$\begin{array}{c}\text { Cimar } 18 \\
\text { Winter, } 2012 \\
(48,122 ; 74 \%) \\
\mathrm{N}=31\end{array}$} & \multicolumn{2}{|c|}{$\begin{array}{c}\text { Cimar } 20 \\
\text { Spring, 2014 } \\
(1.185 ; 5 \%) \\
\mathrm{N}=39\end{array}$} \\
\hline & & $\begin{array}{c}\text { Abundance } \\
(\%)\end{array}$ & $\mathrm{f}$ & $\begin{array}{c}\text { Abundance } \\
(\%)\end{array}$ & $\mathrm{f}$ & $\begin{array}{c}\text { Abundance } \\
(\%)\end{array}$ & $\mathrm{f}$ \\
\hline Nemertea & Müller & 0.01 & 1 & 0 & 0 & 0 & 0 \\
\hline Polychaeta & $\begin{array}{c}\text { Only Polygordius } \\
\text { exolarvae }\end{array}$ & 54.04 & 23 & 0.20 & 5 & 0 & 0 \\
\hline Polychaeta & 10 types & 2.928 & 24 & 0.64 & 20 & 3.54 & 8 \\
\hline Sipunculida & Pelagosphaera & 0.01 & 1 & 0 & 0 & 0 & 0 \\
\hline Barnacles & Nauplius + Cypris & 2.15 & 11 & 0.60 & 15 & 34.96 & 23 \\
\hline $\begin{array}{l}\text { Decapod } \\
\text { crustaceans }\end{array}$ & $\begin{array}{l}\text { Diverse types (6), } \\
\text { mainly nauplius of } \\
\text { copepods }\end{array}$ & 0.92 & 11 & 94.09 & 27 & 28.39 & 19 \\
\hline Bryozoa & Cyphonautes & 8.56 & 19 & 4.44 & 24 & 25.78 & 25 \\
\hline Gastropoda & Bilobed larvae & 0.02 & 2 & 0 & 0 & 0 & 0 \\
\hline Bivalvia & $\begin{array}{c}\text { (right charnel + } \\
\text { umbonated) }\end{array}$ & 28.46 & 18 & 0 & 0 & 0 & 0 \\
\hline Echinodermata & Pluteus & 1.49 & 11 & 0.04 & 4 & 0 & 0 \\
\hline
\end{tabular}


Bryozoa and nauplius and cypris of barnacles were dominant and frequent. In general, la contribution of the meroneuston changed significantly between cruises, where in CIMAR 18 represented to 74\%, while in CIMAR 20 only represented a 5\%. Thus, along the austral zone of Chile prevail different oceanographic condition that could to affect the composition, abundance and biodiversity of the estuarine meroneuston, as is exemplified with the spatial distribution of Polygordius exolarvae.

\section{DISCUSSION}

Polygordius exolarvae living in the neustonic layer of a number of estuarine sites along the southern Chilean coast were studied. This finding is the first reference of Polygordius in southern Chile, despite a large body of research on polychaete in benthic (Rozbaczylo, 1985; Cañete et al. 1999; Cañete et al. 2010; Ortiz \& Quiroga, 2010; Cañete et al. 2012) and pelagic samples (Defren-Janson et al. 1999; Fernández-Severini \& Hoffmeyer, 2005; Aguirre et al. 2012; Guglielmo et al. 2014; Palma et al. 2014; Cañete et al. 2016). This slow confirmation mirrors the history for other specific assignations of Polygordius larvae. In our case, the first viewing of the neustonic samples collected during CIMAR 16 highlights the shape and size of this larval form, absence of chaetae, development of large ciliary trochae and a long trunk. Comparing the morphology from samples collected in Magellan waters (CIMAR 16) and the Moraleda Channel (CIMAR 18) with the exolarvae morphology of P. jouinae (Ramey-Balci \& Ambler, 2014) it was possible to confirm the presence of Polygordius.

\section{Morphology of Polygordius exolarvae}

Polygordius larvae are large and planktonic (Fig. 5a-c), with juveniles reaching lengths of up to $9 \mathrm{~mm}$ (Ramey-Balci \& Ambler, 2014). The smallest $P$. jouinae individual recorded by Ramey (2008) was $2 \mathrm{~mm}$ TL and provides an initial estimate of size at recruitment. Average lengths of specimens collected during CIMAR 16 and 18 was $2.87 \pm 0.81 \mathrm{~mm} \mathrm{TL}$, with individuals of $2.0-2.4$ $\mathrm{mm}$ TL being relatively common, and the largest exolarva being $3.2 \mathrm{~mm}$ TL. Exolarvae of this size were usually in the process of metamorphosis or had recently metamorphosed (Fig. 5a-c). This finding suggests a long planktonic life stage, with recruitment beginning during summer months in Magellan waters (December to February).

The apical organ in Polygordius larvae is believed to function in chemoreception and/ or mechanoreception (Sensenbaugh \& Franzen, 1987; Ramey-Balci \& Ambler, 2014). Benthic adults respond to changes in bottom roughness, such as sediment ripples (Ramey \& Bodnar, 2008; Grassle et al. 2009; Ramey et al. 2009), whose topography can influence the concentration and patchiness of particulate organic matter. However, our specimens did not show a developed apical organ or prostomial tentacles, as found in $P$. jouinae (Ramey-Balci \& Ambler, 2014). Presence of prostomial tentacles in the exolarvae through scanning electronic microscopy (SEM) by Patricia Ramey confirmed recently this denomination.

The exolarvae collected during CIMAR 16 and 18 have some typical morphological features that assist in differentiating them from endolarvae (Ramey-Balci \& Ambler, 2014), namely a lack of pygidial appendages, including glands and cirri, and a much-reduced and flattened hyposphere. Furthermore, early stages are best distinguished based on size, with endolarvae being at least two times larger and generally more robust-looking than exolarvae.

The absence of endolarvae in the three cruises could be due to their comparatively rapid development and change in shape (RameyBalci \& Ambler, 2014). For example, Cowles (1903) provided interesting observations on metamorphosis and growth of endolarvae collected off Beaufort, North Carolina. He described metamorphosis and growth in the endolarvae as rapid, with metamorphosed individuals reaching up to $15 \mathrm{~mm}$ in just 6 weeks. Therefore, it is possible that Polygordius endolarvae do exist, but were simply not part of these neustonic samples, having metamorphosed prior to the CIMAR cruises. Further investigation will be required to assess this possibility.

Spatial distribution of Polygordius exolarvae

Polygordius larvae showed geographic variations in abundance, which seem related 


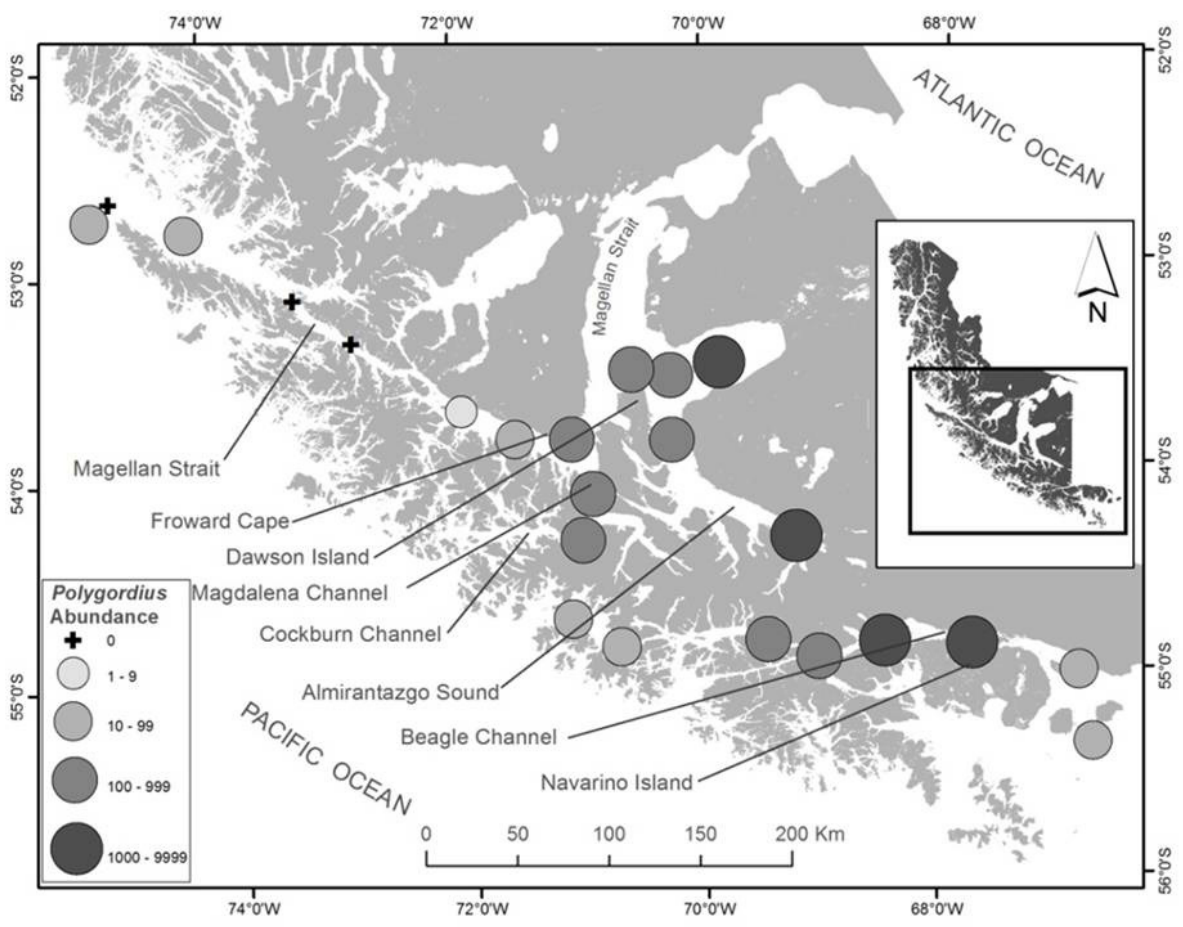

Fig 2. Abundance and spatial distribution of Polygordius exolarvae (individuals per 5 minutes of horizontal drag) along the western margin of Magellan Region (CIMAR 16; Spring, 2010).

to different salinities regimes and freshwater influence in the water column surface layers recorded in the channels and fjords (Table 1; Fig. 2, 3a-b \& 4a-d). The intensive spatial sampling of this study partially characterizes the larval phase of Polygordius, opening new opportunities to understand the life history of this important polychaete from the inner shelf along southern Chile. Salinity records indicate the large variation in estuarine condition of Chilean fjords, making them natural laboratories to study larval transport, dispersal, connectivity and ecophysiology (Iriarte et al. 2014; Cañete et al. 2016). Our results suggest that the abundance of Polygordius exolarvae may be influenced by their position in the brackish water layer and location in coastal areas protected from strong winds during spring. Estuarine areas in Chilean fjord systems have low salinity ( $<27 \mathrm{psu}$ ), which appear to inhibit the presence of Polygordius larvae in coastal waters. However, previous studies of the neustonic copepodites in the west margin of Magellan waters show that oceanographic factors alone make for poor factors when assessing abundances and larval aggregations can be affected significantly by islands or submerged sills (Cañete et al. 2016).

One explanation for the observed abundance distribution is the potential presence of rotational circulation around Dawson Island, which accumulates small plankton living in the surface layers. Submarine topographic features found around Dawson Island and in the Moraleda Channel can contribute to neuston aggregation. Dawson Island has at least one prominent sill (Whiteside Sill; $110 \mathrm{~m}$ depth) and the island blocks the circulation between the eastern and western ends of the Strait of Magellan (Palma et al. 2014), both of which could also act as a plankton retention zone. Indeed, nearly $80 \%$ of the exolarvae were collected around Dawson Island, a pattern similar to copepodites of Microsetella rosea collected during the same cruise (Cañete et al. 2016).

The Moraleda Channel constricts close to Meninea Island $\left(45^{\circ} 16^{\prime} \mathrm{S}, 73^{\circ} 38^{\prime} \mathrm{W}\right)$, where a 50 $m$ deep sill divides the channel into two separated 


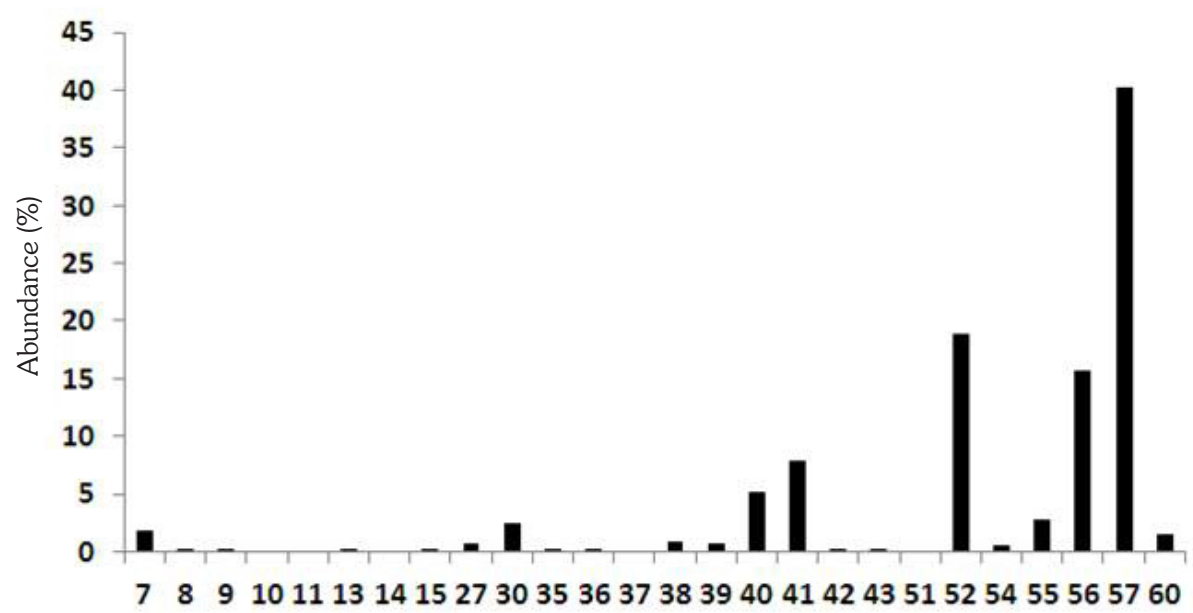

Station number

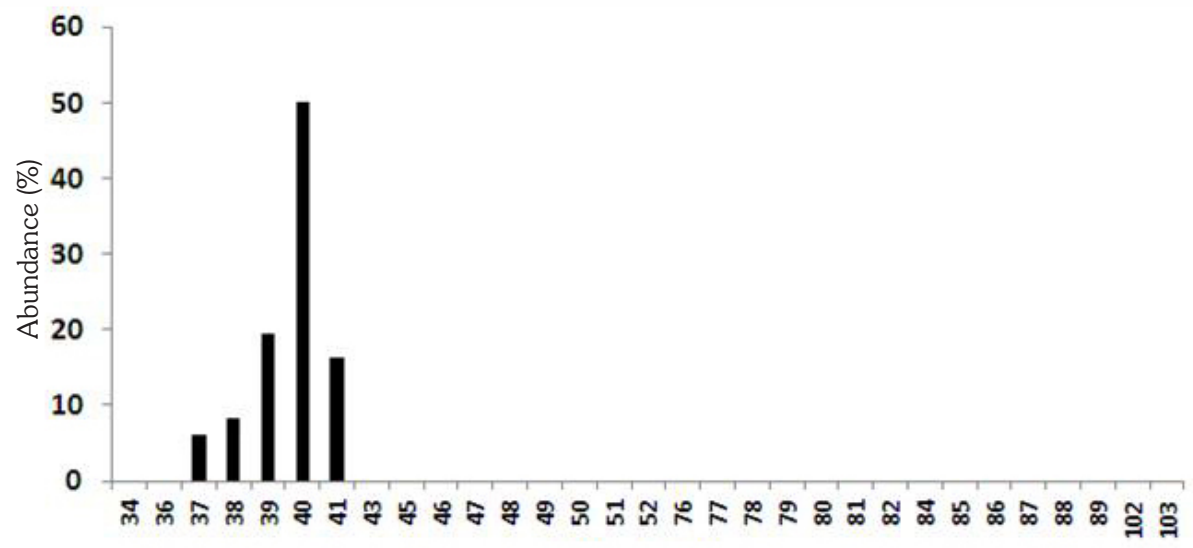

Station number

Fig. 3. Abundance (\%) and spatial distribution of Polygordius exolarvae in the southern Chilean Fjord system: a) Western margin of Magellan Region, CIMAR 16 ( $N=36,328$ individuals), b) Section from the Guafo Channel to Elephant Fjord, CIMAR 18 (N=98 ind.). Exolarvae were not collected during CIMAR 20.

microbasins; the southern microbasin is warmer, less saline, and more oxygenated than the northern microbasin (Silva et al. 1995). There could be surface conditions that produce a frontal zone inducing a neuston aggregation.

The high abundance of exolarvae in the spring could also be indicative a recent spawning event, since larval development lasts two weeks to a month (Ramey-Balci \& Ambler, 2014). Thus, a future research question is to determine if Polygordius exolarvae in these waters derive from adult Polygordius inhabiting the surrounding benthos or if the exolarvae are imported from shallow bottoms of other channels and fjords.
Comparative abundance of Polygordius exolarvae us others meroneustonic taxa

The abundance of Polygordius exolarvae is not homogeneous along fjord system of the southern Chile. This fact could to response to different causes (Table 1, Table 2): 1) wide variations in salinity in latitudinal and longitudinal terms, 2) seasonal variability in the abundance of some dominant holo- and meroplanktonic taxa and 3) presence of sill and fronts, producing aggregation of neuston in surface layer. However, in two cruises (CIMAR 16 and 18) there are coincidences in some taxa living together to Polygordius exolarvae; for example, cyphonautes of Bryozoa, copepodites 

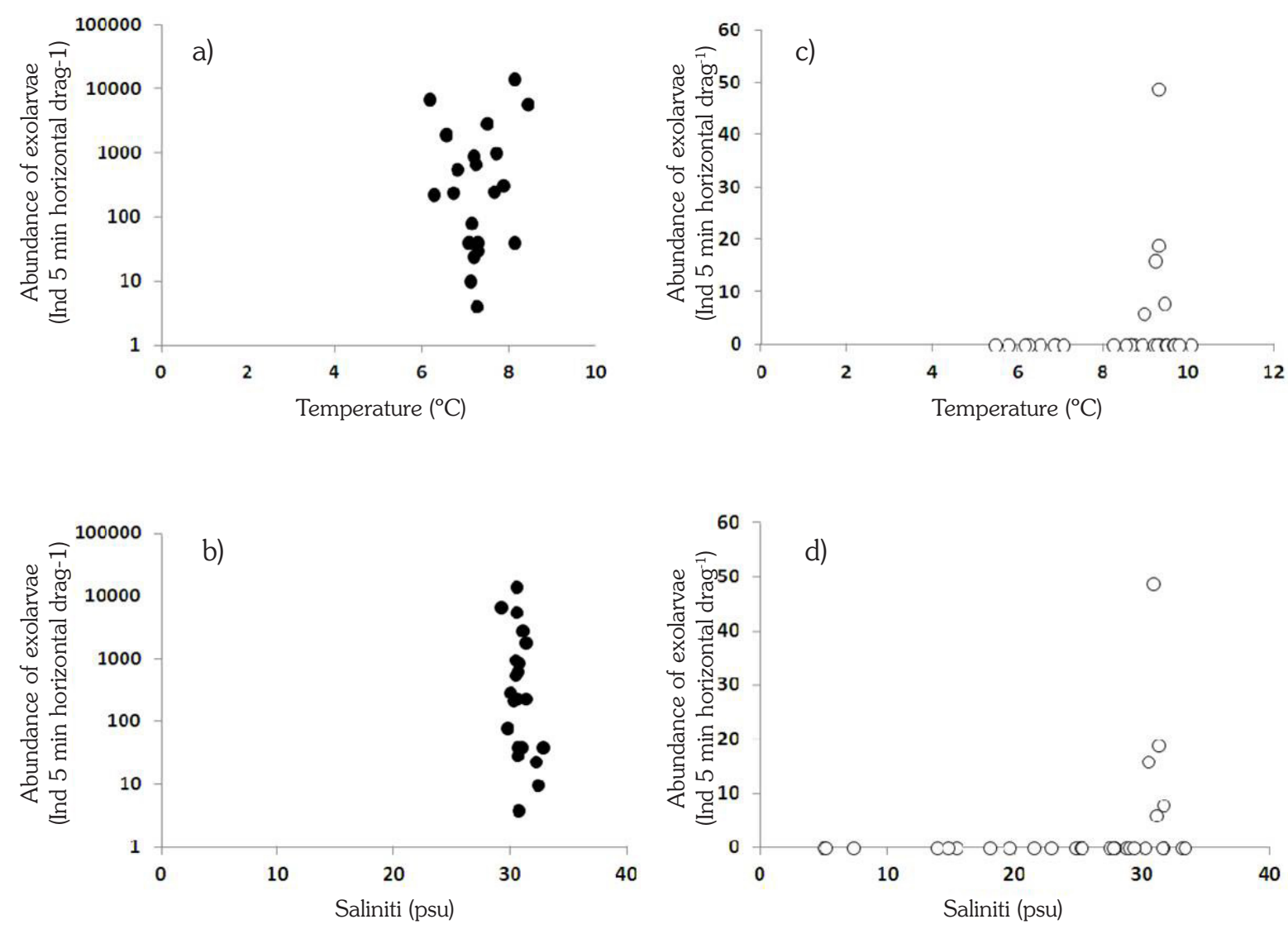

Fig. 4. Influence of temperature and salinity on the abundance and spatial distribution of Polygordius exolarvae in Western margin of Magellan Region (CIMAR 16; a \& b) and between the Guafo Channel and Elephant Fjord (CIMAR 18; c \& d). Abundances are expressed as individuals per 5 minutes of horizontal dragging.

of Microsetella, nauplius and cypris of barnacle and pluteus of echinoderms, which were collected in same locations. It is important highlight the low abundance of meroneuston in the stations sampled during CIMAR 20, where only $5 \%$ of the total abundance corresponds to his organisms with dominance of holoneustonic taxa such as hydromedusae, appendicularia, salps, copepods and euphausida.

Utility of Polygordius exolarvae as biological tracer of neuston aggregation

Polygordius can select muddy and sandy sediments during settlement, with a preference for sandy fractions during flume experiments (Snelgrove et al. 1999), and Polygordius jouinae could be a potential bioindicator of enriched sandy sediment in the east coast of United States (Ramey
\& Bodnar, 2008). Confirming these observations, the sediment characterization of CIMAR Fjord Cruise 3 (1997) reported that the sediments around Dawson Island, Inútil Bay, and Beagle Channel were composed mainly of mud with a small fraction of sand, with $0-2.4 \%$ organic carbon, $0-0.4 \%$ inorganic carbon, and $0-0.2 \%$ Kjieldhal nitrogen (Silva \& Prego, 2002; Silva, 2008).

Furthermore, the size, abundance, frequency, and the consistence appearance of Polygordius exolarvae makes them good candidates for biological trackers (Levin, 1990) of environmental fluctuations in circulatory patterns (Cañete et al. 2016), oceanographic process (Mann \& Lazier, 1991; Garçon et al. 2001), temperature gradients (Valle-Levinson et al. 2006), salinity (Johan et al. 2012), organic enrichment of sediments from aquaculture (Pino et al. 2015), and the productivity along southern 


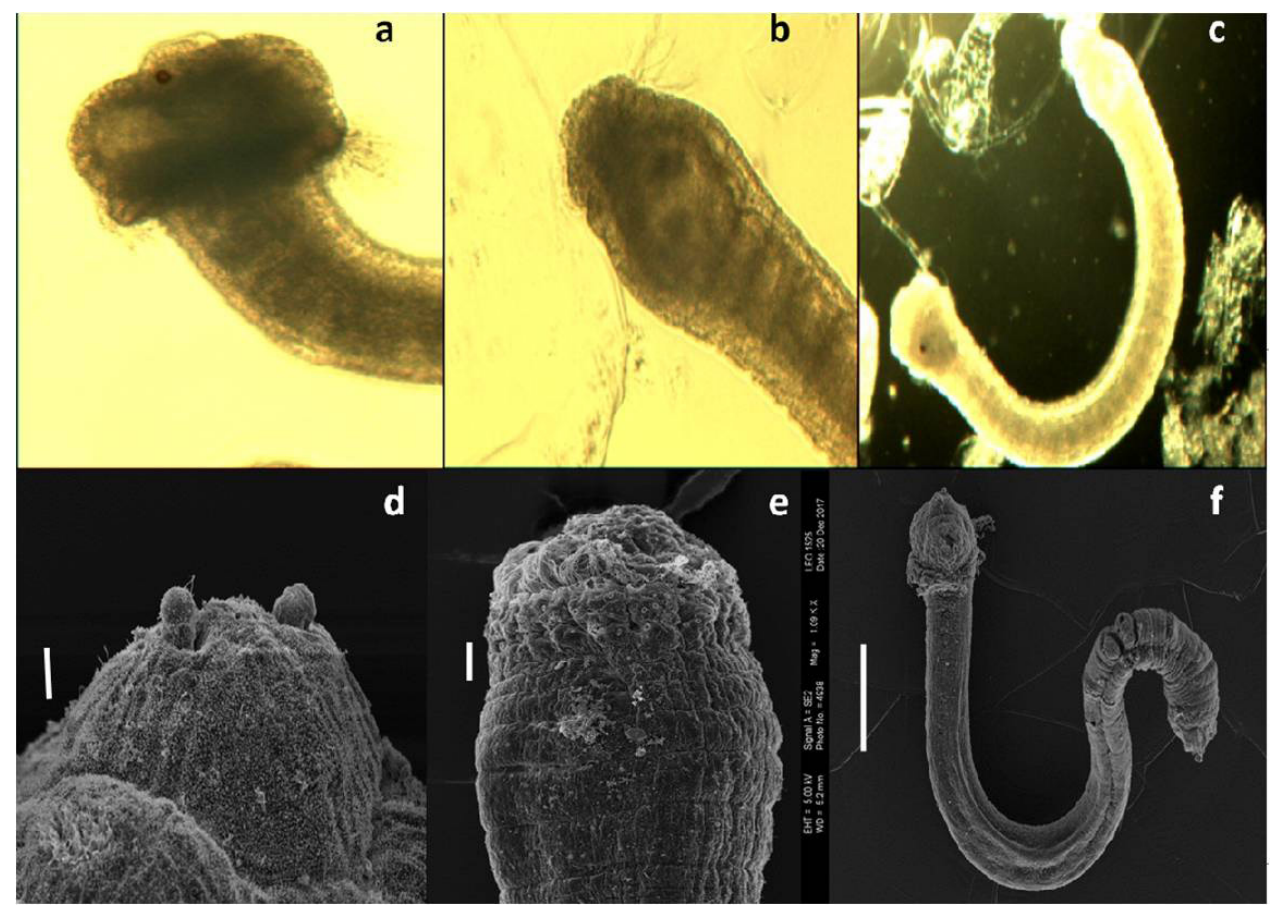

Fig. 5. Polygordius exolarvae collected in neustonic samples of the western margin of Magellan Region, Chile (CIMAR 16). a) Anterior end, with primordial palps, one ocellus, and the ciliary band of the prototroch; b) posterior end of pygidium, showing the telotroch band; c) a complete, preserved neustonic individual (type "banana larvae"). Average exolarva length was $2.87 \pm 0.81$ $\mathrm{mm}(\mathrm{N}=123)$ and the size varied between 1.2 and $5.05 \mathrm{~mm}$ TL.

Chilean estuaries. $P$. jouinae has been shown to vary considerably year-to-year in population abundance, reproduction, and recruitment (Ramey, 2008), and exolarvae show significant changes in terms of abundance and the timing of plankton appearance (Ramey-Balci \& Ambler, 2014). Also, it is possible to differentiate distinct species of Polygordius through larval morphology (Young et al. 2001; Ramey-Balci et al. 2013; Ramey-Balci \& Ambler, 2014).

This study is the first published evidence for the abundance and spatial distribution of neustonic exolarvae from the Polygordius polychaete genus in the coastal waters of southern Chile, with comparisons being made to other neustonic larvae (Table 2). This study also connects the distributional pattern of Polygordius with oceanographic parameters and allow to postulate that the exolarvae of Polygordius have narrow thermal and haline requirements during their pelagic life stage (Fig. $4 a-d)$, being very useful for the monitoring of climate change, pollution and acidification scenery on biological communities living in surface layer of the sea. Thus, along the austral zone of Chile there are different oceanographic regimes associated to change in salinity that could to affect the composition, abundance and biodiversity of the estuarine neuston, allowing the monitoring through of changes in the spatial distribution of Polygordius exolarvae to mesoscale level (Cañete et al. 2017).

\section{ACKNOWLEDGEMENTS}

The authors would like to thank the Hydrographic and Oceanographic Service (SHOA) and the National Center of Hydrographic and Oceanographic Data (CENDHOC) of the Chilean Navy and the financial support granted by CONA C16F 10-014, CONA C18F 12-04 and CONA C20F 14-07. The authors also thank the crews of the RV Abate Molina and the AGS 61 Cabo de Hornos. 


\section{REFERENCES}

Acuña, K., Duarte, C., Jaramillo, E., Contreras, H., Manzano, M., \& Navarro, J. M. (2012). Distribución vertical de la macroinfauna asociada a bivalvos en una planicie intermareal sedimentaria del sur de Chile Vertical distribution of the macroinfauna associated to bivalves in a sedimentary intertidal flat of southern Chile. Revista de Biología Marina y Oceanografía, 47, 383-393.

Aguirre, G. E., Capitanio, F. L., Lovrich, G. A., \& Esnal, G. B. (2012). Seasonal variability of metazooplankton in coastal sub-Antarctic waters (Beagle Channel). Marine Biology Research, 8, 341-353.

Biancalana, F., Barría de Cao, M. S., \& Hoffmeyer, M. S. (2007). Micro and mesozooplankton composition during winter in Ushuaia and Golondrina bays (Beagle Channel, Argentina). Brazilian Journal of Oceanography, 55, 83-95.

Cañete, J. I., Leighton, G. L., \& Aguilera, F. F. (1999). Polychaetes from Aysén Fjord, Chile: distribution, abundance and biogeographical comparison with the shallow soft bottom polychaete fauna from Antarctica and the Magellan Province. Scientia Marina, 63 (Supl. 1), 243-252.

Cañete, J. I., Astorga, M. S., Santana, M., \& Palacios, M. (2010). Abundancia y distribución de Scolecolepides uncinatus Blake, 1983 (Polychaeta: Spionidae) y características sedimentológicas de bahía Lomas, Tierra del Fuego, Chile. Anales Instituto de la Patagonia, 38, 81-94.

Cañete, J. I., Palacios, M. \& Cárdenas, C. A. (2012). Presencia de Cistenides elhersi Hessle, 1917 (Polychaeta: Pectinariidae) en aguas someras magallánicas habitadas por praderas de Ruppia filifolia: evidencia de euribatía, eurihalinidad y euritermia? Anales Instituto de la Patagonia, 40, 125-139.

Cañete, J. I., Gallardo, C., Olave, C., Romero, M. S., Figueroa, T., \& Haro, D. (2016). Abundance and spatial distribution of neustonic copepodites of Microsetella rosea (Harpacticoida: Ectinosomatidae) along the western coast of Magellan, southern
Chile. Latin American Journal of Aquatic Research, 43, 576-587.

Cañete, J. I. Díaz-Ochoa, J. A., Figueroa, T., \& Medina, A. (2017). Infestation of Pseudione tuberculata (Isopoda: Bopyridae) on juveniles of Lithodes santolla (region of Magallanes, Chile): a spatial mesoscale analysis. Latin American Journal of Aquatic Research, 45, 79-93.

Conte, M. H., Weber, J. C., \& Ralph, N. (1998). Episodic particle flux in the deep Sargasso Sea: an organic geochemical assessment. Deep-Sea Research, I, 45, 1819-1841.

Cowles, R. P. (1903). Notes on the rearing of the larvae of Polygordius appendiculatus and on the occurrence of the adult on the Atlantic coast of America. Biological Bulletin (Woods Hole), 4, 125-128.

Dávila, P. M., Figueroa, D., \& Müller, E. (2002). Freshwater Input into the coastal ocean and its relation with the salinity distribution off austral Chile (35-55으. Continental Shelf Research, 22, 521-534.

Defren-Janson, K., Schnack-Schiel, S. B., \& Richter, C. (1999). Mesozooplankton communities in the Magellan region. Scientia Marina, 63, 43-50.

Fernández-Severini, M. D., \& Hoffmeyer, M. S. (2005). Mesozooplankton assemblages in two bays in the Beagle Channel (Argentina) during January 2001. Scientia Marina, 69 (suppl. 2), 27-37.

Garçon, V., Oschlies, A., Doney, S., McGillicuddy, D., \& Waniek, J. (2001). The role of mesoscale variability on plankton dynamics. Deep Sea Research, Part II, 48, 21992226.

Grassle, J. F., Ramey, P. A., \& Petrecca, R. F. (2009). Temporal and spatial variation in infaunal community structure in physically active continental shelf sediments at a long-term ecosystem observatory (LEO-15) off New Jersey, USA. Journal of Marine Research, 67, 869-897.

Guglielmo, R., Gambi, M. C., Granata, A., Guglielmo, L., \& Minutoli, R. (2014). Composition, abundance and distribution of holoplanktonic polychaetes within the Strait of Magellan (southern America) in 
austral summer. Polar Biology, 37, 9991015.

Hamamé, M., \& Antezana, T. (1999). Chlorophyll and zooplankton in microbasins along the Magellan Strait-Beagle Channel passage. Scientia Marina, 63 (Supl. 1), 35-42.

Hardy, J. T. (1991). Where the sea meets the sky. The ocean's skin is the richest, most extensive habitat of all. Natural History, American. Museum of Natural History, 1-3.

Hardy, J. T. (2005). Biological effects of chemicals in the sea-surface microlayer. In P. S. Liss $\&$ R. A. Duce (Eds.), The sea surface and global change (pp. 339-370). Cambridge: Cambridge University Press.

Hays, G. C., Richardson, A. J. \& Robinson, C. (2005). Climate change and marine plankton. Trends in Ecology and Evolution, 20, 337-344.

Hatschek, B. (1878). Studien uber Entwicklungsgeschichte der Anneliden. Ein Beitrag zur Morphologie der Bilaterien. Arbeiten aus dem Zoologischen Institute der Universitat Wien und der Zoologischen Station in Triest, 1, 277-404.

Iriarte, J. L., Pantoja, S. \& Daneri, G.. (2014). Oceanographic processes in Chilean fjords of Patagonia: from small to large-scale studies. Progress in Oceanography, 129, 1-7.

Johan, I., Wasnah, W. O., Mashhor, M., Abu Hena, M. K. \& Amin, S. M. N. (2012). Spatial distribution of copepods along the salinity gradient of Perai River Estuary, Penang, Malaysia. Pakistan Journal of Biological Science, 15, 647-652.

Koski, M., Møller, E. F., Maar, M. \& Visser, A. W. (2007). The fate of discarded appendicularian houses: degradation by the copepod, Microsetella norvegica, and other agents. Journal of Plankton Research, 29, 641-654.

Levin, L. A. (1990). A review of methods for labeling and tracking marine invertebrate larvae. Ophelia, 32, 115-144.

Loven, S. (1843). XIII. Observations on the metamorphosis of an Annelide. Annals and Magazine of Natural History Series, 1, 11,
43-45.

Mann, K. H. \& Lazier, J. R. (1991). Dynamics of marine ecosystems: Biological-physical interactions in the oceans. Massachusetts: Blackwell, Malden.

Marín, V. H. \& Antezana, T. (1985). Species composition and relative abundance of copepods in Chilean Fjords. Journal of Plankton Research, 7, 961-966.

Marín, V. H., \& Delgado, L. E. (2001). La taxocenosis de copepodos calanoídeos en los canales magallánicos: un patrón anidado. Ciencia y Tecnología del Mar, CONA, 24, 81-89.

Mazzocchi, M. G., Zagami, G., Ianora, A., Guglielmo, L., Crescenti, N., \& Hure, J. (1995). Copepods. In L. Guglielmo \& A. Ianora (Eds.), Atlas of marine zooplankton straits of Magellan (253 pp.) Berlin: Springer-Verlag.

Ortiz, P., \& Quiroga, E. (2010). Nuevos registros y distribución de poliquetos bentónicos submareales de fondos blandos en la Región de Aisén, Chile: familias Paraonidae y Spionidae (Annelida: Polychaeta). Anales Instituto de la Patagonia, 38, 59-68

Palma, S, Córdova, P., Silva, N., \& Silva, C. (2014). Biodiversity and spatial distribution of medusae in the Magellan Region (Southern Patagonian Zone). Latin American Journal of Aquatic Research, 42, 1175-1188.

Pantoja, S., Iriarte, J. L., \& Daneri, G. (2011). Oceanography of the Chilean Patagonia. Continental Shelf of Research, 31, 149153.

Pino, L., Marín, S. L., \& Núñez, R. (2015). Indicadores bióticos y fracción de tamaños en la definición de la macrofauna. Latin American Journal of Aquatic Research, 43, 329-336.

Ramey, P. A. (2008). Life history and population dynamics of a dominant polychaete, Polygordius jouinae, in inner continental shelf sands of the Mid-Atlantic Bight, USA. Marine Biology, 154, 443-452.

Ramey, P. A., Fiege, D. \& Leander, B. S. (2006). A new species of Polygordius (Polychaeta: Polygordiidae): from the inner continental shelf and in bays and harbours of the north- 
eastern United States. Journal of the Marine Biology Association of the United Kingdom, 86, 1025-1034.

Ramey, P.A., Grassle, J. P., Grassle, J. F. \& Petrecca, R. M. (2009). Small-scale, patchy distributions of infauna in hydrodynamically mobile continental shelf sands: do ripple crests and troughs support different communities? Continental Shelf of Research, 29, 2222-2233.

Ramey, P. A., \& Bodnar, E. (2008). Selection by a deposit-feeding polychaete, Polygordius jouinae, for sands with relatively high organic content. Limnology and. Oceanography, 53, 1512-1520.

Ramey-Balci, P. A., Fiege, D., \& Purschke, G. (2013). Polygordiida: Polygordiidae Czerniavsky, 1881, Zoology Online. Boston: De Gruyter, Berlin,.

Ramey-Balc1, P. A., \& Ambler, J. W. (2014). Distribution and seasonal abundance of Polygordius spp. (Class: Polychaeta; Family: Polygordiidae) exo- and endolarvae in the southern Mid-Atlantic Bight, USA. Marine Biology, 161, 1565-1581.

Rodríguez, C. A., Browman, H. I., \& St-Pierre, J.-F. (2000). High survival of neustonic zoea I larvae of american lobster Homarus americanus following short-term exposure to ultraviolet (280 to $400 \mathrm{~nm}$ ). Marine Ecology of Progress Series, 193, 305-309.

Rozbaczylo, N. (1985). Los anélidos poliquetos de Chile. Indice sinonímico y distribución geográfica de especies. Monografías Biológicas, Santiago, Chile, 3, 1-284.

Sensenbaugh, T. \& Franzen, A. (1987). Fine structural observations of the apical organ in the larva of Polygordius (Annelida: Polychaeta). Scanning Microscopy, 1, 181189

Silva, N. (2008). Physical and chemical characteristics of the surface sediments in the austral Chilean channels and fjords. In N. Silva \& S. Palma (Eds.), Progress in the oceanographic knowledge of Chilean interior waters, from Puerto Montt to Cape Horn (pp. 69-75). Valparaíso: Escuela de Ciencias del Mar, Pontificia Universidad Católica de Valparaíso

Silva, N., \& Prego, R. (2002). Carbon and nitrogen spatial segregation and stoichiometry in the surface sediments of southern Chilean inlets $\left(41^{\circ}-56^{\circ} \mathrm{S}\right)$. Estuarine Coastal and Shelf Science, 55, 763-775.

Silva, N., \& Palma, S. (Ed.). (2008). Progress in the oceanographic knowledge of Chilean interior waters, from Puerto Montt to Cape Horn. Valparaíso: Escuela de Ciencias del Mar, Pontificia Universidad Católica de Valparaíso.

Silva, N., Sievers, H. A., \& Prado, R. (1995). Características oceanográficas y una proposición de circulación para algunos canales australes de Chile entre $41^{\circ} 20^{\prime} S$ y 4640'S. Revista de Biologia Marina, 30, 207-254.

Snelgrove, P. V. R., Grassle, J. P., Grassle, J. F., Petrecca, R. F. \& Ma, H. (1999). In situ habitat selection by settling larvae of marine soft-sediment invertebrates. Limnology and Oceanography, 44, 1341-1347.

Upstill-Goddard, R. C., Frost, T., Henry, G. R., Franklin, M., Colin Murrell, J., \& Owens, N. J. P. (2003). Bacterioneuston control of air-water methane exchange determined with a laboratory gas exchange tank. Global Biogeochemistry Cycles, 17, 19-15.

Valle-Levinson, A., Blanco, J. L., \& Frangopulos, M. (2006). Hydrography and frontogenesis in a glacial fjord off the Strait of Magellan. Ocean Dynamics, 56, 217-227.

Young, C. M., Sewell, M. A., \& Rice, E. (Eds.). (2001). Atlas of Marine Invertebrate Larvae. Barcelona: Academic Press.

Zaitsev, Y. (2005). Neuston of seas and Oceans. In S. Peter \& R. A. Liss (Eds.), Duce, the sea surface and global change (pp. 371-382). Cambridge: Cambridge University Press. 